\title{
The Application of the Responsive Regulation Theory on Indirect Tax Compliance Among Small and Medium Enterprises in Malaysia
}

\author{
Soliha Sanusi ${ }^{1 \star}$, Normah Omar², Zuraidah Mohd Sanusi², \\ and Istyakara Muslichah ${ }^{3}$ \\ ${ }^{1}$ School of Management, Universiti Sains Malaysia, Penang, Malaysia \\ ${ }^{2}$ Accounting Research Institute, Universiti Teknologi MARA, Shah Alam, \\ Selangor, Malaysia \\ ${ }^{3}$ Department of Management, Faculty of Business and Economics, \\ Universitas Islam Indonesia, Yogyakarta, Indonesia
}

\begin{abstract}
Tax collection is significant for many countries worldwide to cater for their development and social responsibility expenses. Hence, compliance in terms of tax payment from the taxpayers is essential to have a high tax collection. Due to that, this research aimed to deliver empirical evidence on elements that affect indirect tax compliance among small and medium enterprises (SMEs) in Malaysia from the perspective of the Responsive Regulation Theory. A mixed-method approach on 379 SMEs and regulators was used. It was followed by supporting pieces of evidence from the qualitative part of the research using interviews. The study found evidence to support that long-term tax compliance is best accomplished through voluntarism factors such as level of tax knowledge, availability of integrated technology within firms, and motivation in firms. The study contributes to theoretical implications in the taxation area in which the Responsive Regulation Theory stipulates that in the long run, compliance is best achieved through factors related to voluntarism.
\end{abstract}

Keywords: Responsive Regulation Theory, indirect tax, tax compliance, small-medium enterprise, tax knowledge

\section{ARTICLE INFO}

\section{Article History:}

Received: 15 March 2021

Accepted: 15 August 2021

Available online: 31 August 2021

\footnotetext{
* Corresponding Author: Soliha Sanusi, can be reached at solihasanusi@usm.my or +604-653-2588. Full address: School of Management, Universiti Sains Malaysia, 11800 USM, Penang, Malaysia
} 


\section{INTRODUCTION}

There are two types of tax handled by the government of Malaysia: direct tax and indirect tax. The Inland Revenue Board of Malaysia (IRB) handles direct tax and the indirect tax is handled by the Royal Malaysian Customs (RMC). The indirect tax collection is lower than direct tax as the number of indirect taxpayers are lesser than the number of taxpayers paying direct tax. Collection of indirect tax for 2020 was only at RM47.2 billion while it was RM142.67 billion for direct tax. It shows that there are many areas of tax collection that RMC needs to improve on to increase tax collection, especially during this Covid19 situation resulting in an economic downturn. Thus, tax compliance is essential to have a high tax collection and is subsequently used to benefit the people. It is in line with a few sustainable development goals and concerned with no poverty, economic growth, quality education, and good health and well-being. The government may need to depend on external loans if we do not have enough internal funding sources. These external loans would be detrimental to a country's sustainability and development in the long run.

Tax compliance and high tax collection has also become an essential component in every tax department around the world. However, there is a need for a study on the views of taxpayers among SMEs on indirect tax compliance in Malaysia. Many previous studies have focussed on direct tax as it contributes towards more tax collection to a country and involves more taxpayers than indirect tax. However, many people do not realise that they pay indirect tax while using services and goods in the market. Therefore, this research intended to examine the factors affecting indirect tax compliance using the Responsive Regulation Theory. The theory is well known in developed countries but seldom used in the research context of developing countries. Hence, it will contribute to the theories in the tax area, especially in Malaysia. 


\section{LITERATURE REVIEW}

\section{Tax Compliance}

A shadow economy is a term used to describe work activities and business transactions, which represent an essential element of an economy involving goods and services that are usually paid for in cash. Hence, business activities in a shadow economy are not taxable because the authorities cannot reach them. Typical examples of a shadow economy include tax evasion, unlicensed construction, and illegal sales (Farzanegan, Hassan \& Badreldin, 2020). A shadow economy is a part of any given country regardless of its economic status, either developing, in transition, or a developed economy. The size of a shadow economy is directly linked to increased taxation and social security contributions and rising state regulations. It was also concluded that a significant output and state losses could be reduced by combating tax evasion and corruption.

Tax evasion is pricey to a state government. The United State of America' Inland Revenue Service had estimated that one out of sixth dollars of taxes due to the Federal Government was not paid in 2019 (IRS, 2016), which can be used to reduce the US Federal budget deficit by one third (Gale \& Krupkin, 2019). High tax compliance is vital to reduce tax evasion. Tax compliance is defined as taxpayers' preparedness to follow all rules and regulations regarding tax, declaration of the correct tax amount, and payment made within the specified times (Slemrod, 2019). Henceforth, compliance events by regulators, mass media, and other entities are vital in providing a better understanding of indirect tax among SMEs (Yusof, Lai \& Wah, 2014). There are six factors applied in this study, namely technology, tax knowledge, SME motivation, tax practice, penalty enforcement policy and audit probability.

The Responsive Regulation Theory applied in this study was introduced by John Braithwaite in 1985 and was further refined in 1995 with Ian Ayres (Freedman, 2011). It recognizes that regulatory agencies may detect and enforce every contravention of the law that it administers. Therefore, regulators should encourage taxpayers to adhere to the law voluntarily. This Theory aims to stimulate the maximum level of regulatory enforcement. According to this Theory, the legal system requires citizens 
of a country to learn the working of its legal institutions in a responsive manner (Braithwaite, 2011). The responsive regulation also requires that regulators be more responsive in regulating and deciding whether an intervention response is needed or otherwise. The Theory also suggests opting for less intrusive actions on voluntarism and acting as intrusive as possible in enforcing the regulations (Braithwaite, 2007). It encourages the community to foster common goals, understandings and mutually enforced the agreed-upon standards. It also prefers education, persuading and encouraging those whoever fall short. Punishment is only necessary to achieve regulatory objectives.

Based on the discussion of the Responsive Regulation Theory, the independent variables in the study were categorised into voluntarism and enforcement factors. Voluntarism factors are internal self-regulating mechanisms initiated and practiced by taxpayers. The Responsive Regulation Theory posits that taxpayer's compliance towards a given regulation is enhanced when their own personal capability and practices are improved and recognised by external parties such as the RMC. Enforcement factors are regulating mechanisms enforced by external agencies such as the RMC to ensure proper compliance by taxpayers. Based on the theory compliance may also be accomplished through enforcement in a situation where the internal capabilities of taxpayers are weak and inadequate. The subsequent subsection will address all the elements related to both voluntarism and enforcement factors of the research framework

\section{Technology}

The revolution of technology and the emergence of the globalised environment has resulted in more complicated compliance issues. Therefore, there is an urgent need to ensure that revenue collection is more efficient and effective without any bureaucracy. It can be described as a collection of techniques, methods, or processes used to accomplish an objective or mission. It can be embedded in any device, machines, computers, tablets, and other hardware. An adequate and efficient technological structure is essential to enable system adoption and usage (Venkatesh, Morris, Davis, \& Davis, 2003).

Electronic tax filing in Malaysia, also known as e-filing, was introduced for corporate tax filing in 2001 and personal tax filing by the 
IRBM in 2005 (Hassan, Nawawi \& Puteh, 2016). For indirect tax, the RMC had introduced MySST in 2018. MySST aims to extend the services to the citizens effectively by enhancing their communication process in the tax system. The RMC has been continuously encouraging online filing systems for its indirect tax submission and payment. It had been used to reduce transaction costs and speed up communication between taxpayers and the RMC (Gruber, 2014). This form of MySST depends on a self-assessment system whereby the regulator trusts the taxpayer to enter the information themselves.

\section{Tax Knowledge}

Knowledge also plays a vital role in emerging countries like Malaysia, as its people tend to read less as compared to citizens in developed countries. Tax knowledge can be enhanced through reading. Malaysians read an average of fifteen books a year (NST,2020).

A study by Hassan et al. (2016) stated that tax education has always been the central focus of tax authorities in Malaysia. The study discussed knowledge requirements, perceived opportunities, and decisions on tax compliance within the IRBM. It consisted of 70 respondents, and data was gathered through survey questionnaires. The study found that the tax education programs by the tax authorities were ineffective as the mediums were deemed 'unattractive' and not easily understandable. Another research by Jamel \& Popoola (2021) acknowledged that tax knowledge plays a part in public acceptance of the new sales and service (SST) tax implementation.

Higher tax knowledge principally leads to a positive view of a tax system (Bidin, Marimuthu, Derashid, Idris, \& Ahmad, 2016). The higher the tax knowledge, the better the understanding of the issues surrounding tax compliance. It was also noted that with higher tax knowledge, taxpayers will consider the consequences of tax evasion more seriously (Fallan, 1999). However, a study by McKerchar (1995) noticed that small businesses were not aware of their tax knowledge deficit. Consequently, it may lead to an unintentional non-compliant behaviour. The RMC should maintain an effective communication channel with the taxpayers to educate them on their rights and responsibilities. It is especially true in the self- assessment system era. Knowledge of taxation is essential to create awareness and to 
promote a sense of responsibility among SMEs. It holds true for taxpayers in developing countries where knowledge seeking is not a culture.

\section{SME Motivation}

Accepted norms in the SMEs and its surrounding society are also important as a factor of compliant behaviour (Heryanto, Mursalim, \& Lannai, 2020). It is related to their attitude towards revenue authorities and their belief in indirect tax benefits. Motivation is essential for SMEs as it provides a roadmap to their organisational goals. Motivation is also important to better understand a company and eventually contribute to performance improvement. According to Cooper and Nguyen (2019), motivation is used to reflect the respondent's underlying judgments or evaluation of any issues in taxation. Motivation on indirect tax refers to the taxpayer's intrinsic drive to pay taxes (Pope \& Mohd Ali, 2010). Cooper and Nguyen (2019) described tax motivation as the driver or values held by firms about paying taxes. On the other hand, tax compliant behaviours refer to the typical and repeated attitude of taxpayers towards tax compliance. Three dimensions were selected to investigate the factors motivating the study, which are attitude, perceived norm, and self-monitoring.

\section{Tax Practice}

Tax practice can be defined as accomplishing routine activities to gain proficiency in a particular field (Tsang, Mehta, Lee \& Wong, 2015). Studies on taxpaying behaviour have revealed that one of SME's main issues is their ability to pay tax on time (Abdul-Jabbar, Abuamria, Alkhatib, \& Marimuthu, 2020). It can mainly be attributed to the effect of tax payment on their cash flow. Although they are fully aware of their responsibility to pay their tax, simultaneously, as profit-maximisation entities, they will always view them as a burden due to its costs.

Inasius (2019) found that SMEs often have insufficient information on tax regulation to meet their obligations. They are also mostly unaware of what they need to do to minimise their tax payment. Many SMEs in Australia rely heavily on tax advisors/agents to complete their tax returns. In most cases, taxpayers look for tax agent's assistance because they want to conduct their business operation hassle-free (Sakurai \& Braithwaite, 
2019). However, their top-ranked motivation to prepare a correct tax return is to reduce the likelihood of being penalised. Nevertheless, few taxpayers do seek assistance from tax agents to engage in aggressive tax avoidance practices.

\section{Penalty Enforcement Policy}

A study by Gómez and Mironov (2015) on tax enforcement after the election of Vladimir Putin as the President of Russia in 2000 investigated the possibility of tax enforcement as an instrument to curb income diversion by managers and controlling shareholders in Russia. The study involved 156 large Russian firms in diverse industries using panel data from 1999 to 2004. The findings supported the study hypotheses that tax enforcement is associated with a reduction in private rents and by insiders from the firms investigated for tax evasion. Tax enforcement also reduced income diversion practices by most public firms in Russia. Hence, it shows that tax enforcement can act as a powerful mechanism to curb non-compliance or any wrongdoers in the tax industry (Slemrod, 2020).

Another investigation in the local context by Mohd Ali, Isa, and Yusoff (2014) found that the threat of punishment is a useful tool to deter tax non-compliance. However, the effect of such punishment was considered insignificant by law-abiding taxpayers. The study centered on self-employed, personal income taxpayers by using self-administered and online surveys. From the 302 responses received, it was found that taxpayers tended to avoid and evade tax when they feel threatened with tax authorities' audits and penalties. Jamel et al. (2021) had studied the role of tax authorities (RMC) in the local context. They found that enforcement authorities played a role in public acceptance of the new sales and service tax implementation.

\section{Audit Probability}

The auditors have a right to full access to detailed financial information, including contracts in hand, payments, receipts, and tax invoices. An audit was found to be a powerful tool to improve the compliance level among SMEs (Gómez \& Mironov, 2015). Empirical research on audit probability provided mixed evidence for the occurrence of audit probability (Beer, 
Kasper, Kirchler \& Erard, 2015; Gangl, Torgler, Kirchler \& Hofmann, 2014). The result of an audit from the regulator can be either have a positive or negative or null effect on tax compliance (Devos, 2014; Lederman, 2016). Notwithstanding, the effect is highly dependent on the type of items asked by the tax regulator, as it will lead to the respondents' unique perspective on the audit itself.

\section{FRAMEWORK AND HYPOTHESES DEVELOPMENT}

Based on the Responsive Regulation Theory as the underlying theory and the literature relating to indirect tax compliance in Malaysia, a theoretical framework was established, as shown in Figure 1.

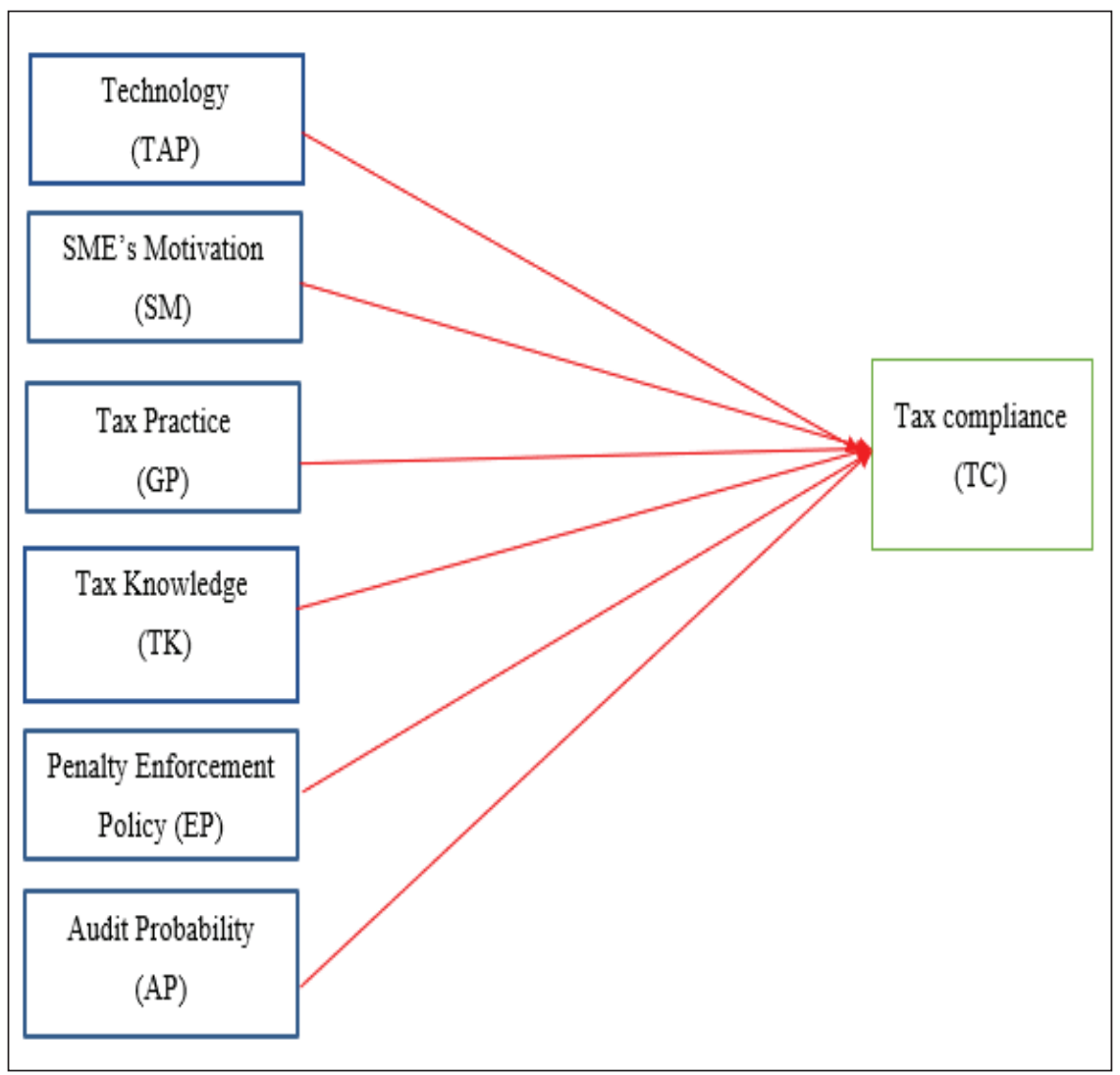

Figure 1: Research Framework based on Responsive Regulation Theory 
A few hypotheses were established to assess the result of the discussion, as mentioned above in the literature review. The four variables above (audit probability, penalty enforcement policy, tax knowledge, and technology) are related to the Responsive Regulation Theory. The author added another two variables (SME motivation and tax practice) to enhance and contribute to the theory. The hypotheses are expressed below:

H1: There is a positive relationship between technology and indirect tax compliance among SMEs in Malaysia.

H2: There is a positive relationship between tax knowledge and indirect tax compliance among SMEs in Malaysia.

H3: There is a positive relationship between SMEs motivation and indirect tax compliance among SMEs in Malaysia.

H4: There is a positive relationship between tax practice and indirect tax compliance among SMEs in Malaysia.

H5: There is a positive relationship between penalty enforcement policy and indirect tax compliance among SMEs in Malaysia.

H6: There is a positive relationship between audit probability and indirect tax compliance among SMEs in Malaysia.

\section{METHODOLOGY}

This study applied a mixed method by using a sequential explanatory approach. A pilot study by interviewing experts from the RMC and top management personnel from the industry was critical to get a sense of the factors to study.

It continued with a survey questionnaire in the quantitative part. The survey questionnaires were distributed to 1200 respondents registered with the RMC. A total of 404 questionnaires were returned, and out of it, 379 were completed, whereas the others were rejected. The respondents were expected to answer the questions using the Likert scale of 7, ranging from 
1 for strongly disagree to 7 for strongly agree. The items for the variables were from Isa (2012) and the Attitude and Behaviour Tax and Compliance, Ireland, study for 2013. The data was then analysed using the Smart PLS 3.0 for inferential analysis.

After that, personal interviews were applied to gather information from SME owners in Malaysia. Eight respondents were selected who were active participants in early 2017. An interview of almost one hour was then conducted with each of these respondents. A focus group interview was conducted for the RMC officers in 2017 to get feedback from the regulator. Five respondents from three related departments in the headquarters, Putrajaya, were willing to contribute to the study by sharing any nonconfidential material. Two hours of focus group discussion was required to obtain satisfactory replies to the queries arranged by the investigator.

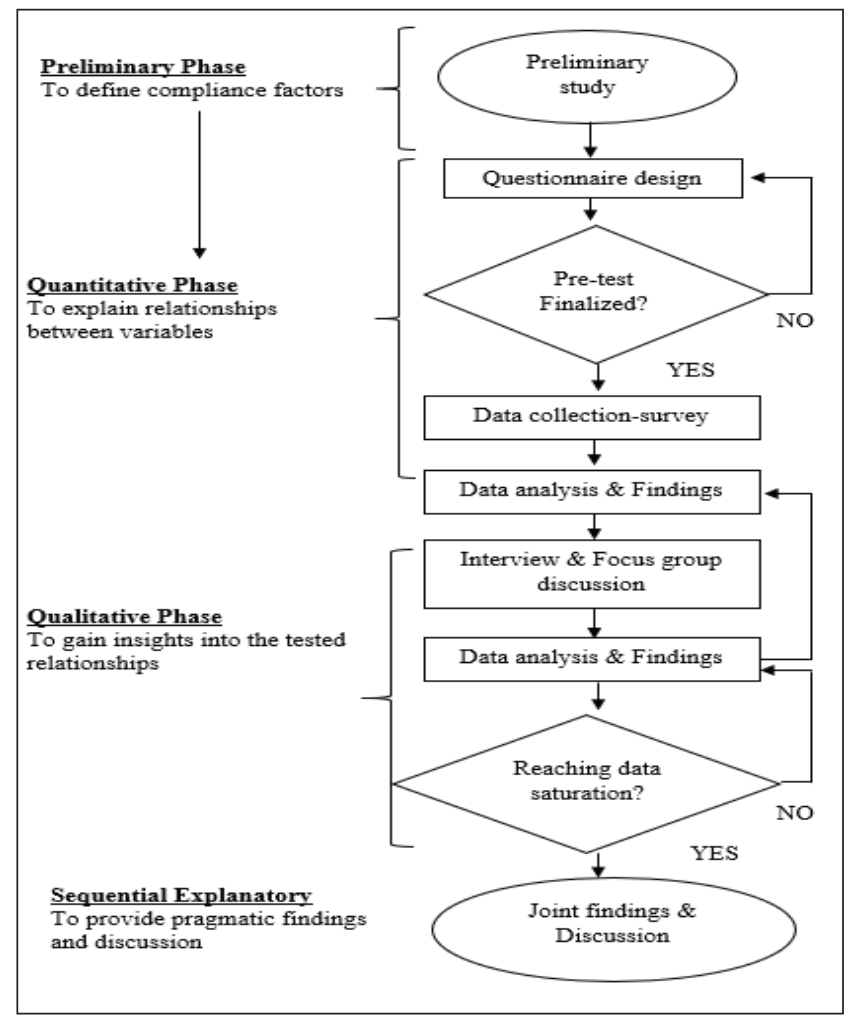

Figure 2: Sequential Explanatory Mixed-Method Design 
The sequential explanatory design summarised in Figure 2 was considered the most appropriate design as it used a qualitative approach to complement the findings from the quantitative study. The combination of the two methods would provide more realistic and meaningful discoveries and more significance to the context of the research (Granek \& Nakash 2016).

\section{RESULTS AND DISCUSSION}

The findings are first presented for the quantitative stage and followed by the qualitative phase. In terms of demographic factors, out of the 379 respondents, $150(40 \%)$ were Male, and 229 (60\%) female. Besides, 60\% of the respondents were between thirty to fifty years old. Almost twothirds of the respondents had a first degree and above. Therefore, they can understand indirect tax quite well. Moreover, $63 \%$ of the respondents came from medium sized SMEs. The following section will elaborate analysis of the survey questionnaire for the study.

\section{Quantitative Phase - Measurement Model}

Construct validity was first determined before the hypothesis testing could be performed. Table 1 shows the reliability and validity of the data collected. A composite reliability (CR) of more than 0.70 proves that the variables hold an acceptable level of internal uniformity (Gefen, Straub, \& Boudreau, 2000). Equally, the variables under study reached the minimum threshold value of 0.5 for the average variance extracted (AVE). Thus, it established a good convergent validity (Bagozzi \& Yi 1988), and it clarified that the items described more than $50 \%$ of the variances in the constructs (Hair, Hult \& Ringle 2014). Henceforth, all the items were maintained for further analysis. 
Table 1: Internal Consistency and Convergent Validity

\begin{tabular}{|c|c|c|c|c|}
\hline Construct & Item & Loading & $\begin{array}{l}\text { Composite } \\
\text { Reliability }\end{array}$ & AVE \\
\hline \multirow[t]{12}{*}{ Compliance } & Disclosure 1 & 0.846 & 0.955 & 0.642 \\
\hline & Disclosure 2 & 0.860 & & \\
\hline & Disclosure 3 & 0.899 & & \\
\hline & Disclosure 4 & 0.838 & & \\
\hline & Disclosure 5 & 0.880 & & \\
\hline & Remittance 1 & 0.808 & & \\
\hline & Remittance 2 & 0.881 & & \\
\hline & Remittance 3 & 0.766 & & \\
\hline & Submission 1 & 0.614 & & \\
\hline & Submission 2 & 0.771 & & \\
\hline & Submission 3 & 0.785 & & \\
\hline & Submission 4 & 0.599 & & \\
\hline \multirow[t]{10}{*}{ Indirect Tax Knowledge } & General 1 & 0.828 & 0.933 & 0.583 \\
\hline & General 2 & 0.855 & & \\
\hline & General 3 & 0.678 & & \\
\hline & General 4 & 0.824 & & \\
\hline & General 5 & 0.839 & & \\
\hline & Qualification 1 & 0.737 & & \\
\hline & Qualification 2 & 0.671 & & \\
\hline & Qualification 3 & 0.667 & & \\
\hline & Qualification 4 & 0.775 & & \\
\hline & Qualification 5 & 0.731 & & \\
\hline \multirow[t]{10}{*}{ Technology } & Technology 1 & 0.822 & 0.937 & 0.601 \\
\hline & Technology 2 & 0.867 & & \\
\hline & Technology 3 & 0.816 & & \\
\hline & Technology 4 & 0.857 & & \\
\hline & Technology 5 & 0.778 & & \\
\hline & System 1 & 0.672 & & \\
\hline & System 2 & 0.753 & & \\
\hline & System 3 & 0.583 & & \\
\hline & System 4 & 0.775 & & \\
\hline & System 5 & 0.784 & & \\
\hline \multirow[t]{5}{*}{ SME Motivation } & Attitude 1 & 0.744 & 0.898 & 0.527 \\
\hline & Attitude 2 & 0.596 & & \\
\hline & Perceive norm 1 & 0.646 & & \\
\hline & Self-monitoring 1 & 0.856 & & \\
\hline & Self-monitoring 2 & 0.718 & & \\
\hline
\end{tabular}




\begin{tabular}{|c|c|c|c|c|}
\hline Construct & Item & Loading & $\begin{array}{l}\text { Composite } \\
\text { Reliability }\end{array}$ & AVE \\
\hline & Self-monitoring 3 & 0.842 & & \\
\hline & Self-monitoring 4 & 0.707 & & \\
\hline & Self-monitoring 5 & 0.655 & & \\
\hline \multirow[t]{8}{*}{ Indirect Tax Practice } & Practice 1 & 0.718 & & 0.916 \\
\hline & Practice 2 & 0.799 & & \\
\hline & Practice 3 & 0.828 & & \\
\hline & Practice 4 & 0.833 & & \\
\hline & Practice 5 & 0.752 & & \\
\hline & Practice 6 & 0.803 & & \\
\hline & Practice 7 & 0.638 & & \\
\hline & Practice 8 & 0.691 & & \\
\hline \multirow[t]{6}{*}{ Enforcement by Regulator } & Certainty 1 & 0.824 & 0.934 & 0.702 \\
\hline & Certainty 2 & 0.886 & & \\
\hline & Swift 1 & 0.876 & & \\
\hline & Swift 2 & 0.853 & & \\
\hline & Severity 1 & 0.787 & & \\
\hline & Severity 2 & 0.798 & & \\
\hline \multirow[t]{8}{*}{ Audit Probability } & Audit probability 1 & 0.635 & 0.932 & 0.634 \\
\hline & Audit probability 2 & 0.736 & & \\
\hline & Audit probability 3 & 0.836 & & \\
\hline & Audit probability 4 & 0.834 & & \\
\hline & Audit activity 1 & 0.881 & & \\
\hline & Audit activity 2 & 0.836 & & \\
\hline & Audit activity 3 & 0.766 & & \\
\hline & Audit activity 4 & 0.818 & & \\
\hline
\end{tabular}

Table 2 shows an assessment of discriminant validity using the FornellLacker criteria (Kline, 2011). The requirement for discriminant validity is that two constructs should be genuinely distinct from one another. The correlation values corresponding to the respective constructs did not violate this requirement. Hence, it can be concluded that validity was present in the measurement model developed. 
Table 2: Discriminant Validity based on Fornell-Lacker Criterion

\begin{tabular}{lccccccc}
\hline \multicolumn{1}{c}{ Construct } & $\mathbf{1}$ & $\mathbf{2}$ & $\mathbf{3}$ & $\mathbf{4}$ & $\mathbf{5}$ & $\mathbf{6}$ & $\mathbf{7}$ \\
\hline 1.Audit Probability (AP) & 0.796 & & & & & & \\
2.Penalty Enforcement (EP) & 0.485 & $\mathbf{0 . 8 3 8}$ & & & & & \\
3.Indirect tax Compliance (CL) & 0.408 & 0.233 & $\mathbf{0 . 8 0 1}$ & & & & \\
4.Tax Knowledge (TK) & 0.481 & 0.307 & 0.695 & $\mathbf{0 . 7 6 4}$ & & & \\
5.Tax Practice (TP) & 0.320 & 0.250 & 0.208 & 0.258 & $\mathbf{0 . 7 6 1}$ & & \\
6.SME's Motivation (SM) & 0.520 & 0.297 & 0.620 & 0.658 & 0.239 & $\mathbf{0 . 7 3 6}$ & \\
7. Technology (TAP) & 0.455 & 0.240 & 0.675 & 0.701 & 0.261 & 0.692 & $\mathbf{0 . 7 7 5}$ \\
\hline
\end{tabular}

\section{Quantitative Phase - Structural Model}

The study needed to resolve collinearity issues between the variables before performing structural model analysis. As indicated in Table 4 the variance inflation factor (VIF) value for each variable was lower than the stringent value of 3.3 (Diamantopoulos \& Siguaw 2006). Therefore, collinearity was not an issue in this study.

As indicated in Table 3 the findings of the co-efficient of determination $\left(\mathrm{R}^{2}\right)$, the effect size $\left(\mathrm{f}^{2}\right)$, and the cross-validated redundancy $\left(\mathrm{Q}^{2}\right)$ of exogenous constructs on endogenous constructs. The value for the co-efficient of determination $\left(\mathrm{R}^{2}\right)$ of 0.571 proposed that the exogenous variables in this study explained $57.1 \%$ of variances in indirect tax compliance; a suggestion of important explanatory measurements (Cohen, 1992). The blindfolding process was used as the focus of PLS-SEM is on forecasting (Chin, 1998).

Table 3: Determination of Co-efficient $\left(\mathbf{R}^{2}\right)$, Effect Size $\left(\mathrm{f}^{2}\right)$ and Predictive Relevance $\left(\mathbf{Q}^{2}\right)$

\begin{tabular}{lrlll}
\hline \multicolumn{1}{c}{ Item } & VIF & F square & R square & Q square \\
\hline Technology, System and Procedure (TAP) & 2.657 & 0.059 & & \\
Tax Knowledge (TK) & 2.357 & 0.129 & & \\
SME's Motivation (SM) & 2.804 & 0.040 & 0.571 & 0.339 \\
Tax Practice (TP) & 1.151 & 0.000 & & \\
Penalty Enforcement Policy (EP) & 1.339 & 0.000 & & \\
Audit Probability (AP) & 1.737 & 0.000 & & \\
\hline
\end{tabular}


It was suggested that all exogenous variables possessed predictive relevance over the endogenous variable (Fornell \& Cha 1994) as the $Q^{2}$ values were 0.339 , which is larger than 0 . The effect size of the predictor $\left(\mathrm{f}^{2}\right)$ was evaluated by using the size of the predictor indicated that the value of tax knowledge on indirect tax compliance was 0.129 ; which gave a medium effect size (Cohen,1992). The rest had a small or no effect size at all.

Table 4 reveals the outcomes for each path relationship in the model by using the bootstrapping process. The results suggested that several factors were significant at the $99 \%$ confidence level. The factors included tax knowledge, technology, and motivation of SMEs (TK $\rightarrow$ CL, $\beta=0.226$, $\mathrm{p}<0.01 ; \mathrm{TAP} \rightarrow \mathrm{CL}, \beta=0.259, \mathrm{p}<0.01 ; \mathrm{SM} \rightarrow \mathrm{CL}, \beta=0.220, \mathrm{p}<0.01)$. The most prominent factor was tax knowledge, as it played a substantial part in indirect tax implementation (Hofmann, Voracek, Bock, \& Kirchler, 2017). The outcome also proposed that penalty enforcement policy, tax practice, and audit probability were not meaningfully correlated with indirect tax compliance.

In summary, only three hypotheses in the research were supported. Hence, some variables under the Responsive Regulation Theory were supported, such as technology and tax knowledge. The other two variables, audit probability and penalty enforcement, were not supported as respondents preferred to comply voluntarily.

Theoretically, based on various studies conducted in developed countries (e.g. Baldwin \& Black, 2008; Braithwaite, Murphy \& Reinhart, 2007), it is suggested that voluntarism factors play a more prominent role in managing compliance compared to that of enforcement factors. Baldwin and Black (2008) in their study of UK environmental and fisheries control found that the voluntarism factor was a prominent factor in environmental compliance. Quantitative results from this study found the same result. However, findings from the qualitative part support the significance of audit and enforcement policy factors for tax regulators. 
Table 4: Path Coefficient Assessment

\begin{tabular}{|c|c|c|c|c|c|c|}
\hline $\mathbf{H}$ & Variable & $\begin{array}{l}\text { Beta } \\
\text { Coeff. }\end{array}$ & $\begin{array}{l}\text { Std. } \\
\text { Error }\end{array}$ & T Values & P Values & Decision \\
\hline $\mathrm{H} 1$ & $\begin{array}{l}\text { Technology (TAP) -> Tax } \\
\text { Compliance (CL) }\end{array}$ & 0.259 & 0.054 & 4.785 & $0.000^{*}$ & Supported \\
\hline $\mathrm{H} 2$ & $\begin{array}{l}\text { Tax Knowledge (TK) -> Tax } \\
\text { Compliance }(\mathrm{CL})\end{array}$ & 0.361 & 0.071 & 5.082 & $0.000^{*}$ & Supported \\
\hline $\mathrm{H} 3$ & $\begin{array}{l}\text { SME' motivation (SM) -> Tax } \\
\text { Compliance }(\mathrm{CL})\end{array}$ & 0.220 & 0.066 & 3.326 & $0.001^{*}$ & Supported \\
\hline $\mathrm{H} 4$ & $\begin{array}{l}\text { Tax Practice (GP) }->\text { Tax } \\
\text { Compliance }(\mathrm{CL})\end{array}$ & -0.008 & 0.040 & 0.208 & 0.835 & $\begin{array}{c}\text { Not } \\
\text { Supported }\end{array}$ \\
\hline H5 & $\begin{array}{l}\text { Penalty Enforcement }(E P)> \\
\text { Tax Compliance }(C L)\end{array}$ & -0.008 & 0.037 & 0.225 & 0.822 & $\begin{array}{c}\text { Not } \\
\text { Supported }\end{array}$ \\
\hline $\mathrm{H} 6$ & $\begin{array}{l}\text { Audit Probability (AP) -> Tax } \\
\text { Compliance (CL) }\end{array}$ & 0.007 & 0.046 & 0.146 & 0.884 & $\begin{array}{c}\text { Not } \\
\text { Supported }\end{array}$ \\
\hline
\end{tabular}

\section{Qualitative Stage}

As opposed to the quantitative study conducted earlier, the informants for the qualitative research were asked open-ended questions such as "how do you deal with indirect tax implementation in your company?" By asking open-ended questions, the answers varied, and it may not relate to factors in the existing literature. It had been noticed that some aspects were not favourable to the SME, as it required them to work hard. For example, penalty enforcement by the regulator required the SMEs to record their transactions meticulously.

From the SME's standpoint, their accounting software and staff technical knowledge on indirect tax was critical to ensure they meet the requirements as well as the dateline set by the RMC. This is in line with the theory applied in the study as knowledge is very important for the taxpayers to comply. It had been noticed that some owners of companies would bring together their staff during the interview as it is their staff who handle the indirect tax related matters most of the time. Due to that, the owners were willing to send their staff for external training at their own expense.

From the RMC's point of view, the audit and penalty enforcement process assisted the RMC in retrieving indirect tax arrears. Furthermore, the RMC's IT system was highly capable of detecting suspicious activities. The Risk Adjustment Division further investigated red flags that were raised 
by the system. The system thoroughly monitored all the submissions of the indirect tax returns. Any suspicious submission will be verified before the refund (if any) process. The officers will carry out analysis and further investigation to verify/disprove the red flags. All this information helped to disapprove the hypothesis that there is no relationship with indirect tax compliance, such as audit probability and enforcement policy. Thus, audit and penalty enforcement are essential variables for taxpayers to comply with, as mentioned in the Responsive Regulation Theory. Regulators needed to use both functions to enhance compliance among taxpayers. Table 5 shows selected quotes on the perception of SMEs towards indirect tax compliance in Malaysia.

Table 5: Perception of SME Towards Indirect Tax Compliance

\begin{tabular}{|c|c|c|}
\hline Theme & Codes & Selected quotes from transcripts \\
\hline $\begin{array}{l}\text { Technology and Procedure } \\
\text { of tax }\end{array}$ & $\begin{array}{l}\text { Accounting } \\
\text { system }\end{array}$ & $\begin{array}{l}\text { "The accounting system provided is okay for } \\
\text { our company. It just that I need to double key } \\
\text { in some transaction, as it is not integrated with } \\
\text { our current system." }\end{array}$ \\
\hline Tax Knowledge & Training & $\begin{array}{l}\text { "We send our staff for training to improve our } \\
\text { understanding of indirect tax." }\end{array}$ \\
\hline Penalty Enforcement & Penalty & $\begin{array}{l}\text { "The penalty for each mistake is costly. One } \\
\text { company may have committed a few errors." }\end{array}$ \\
\hline Audit Probability & Audit & $\begin{array}{l}\text { "Many of my friends have been audited, and it } \\
\text { scares us. We need to prepare for that." }\end{array}$ \\
\hline SME's motivation & Ethics & "Ethics will lead to better compliance." \\
\hline Tax Practice & Officer's & $\begin{array}{l}\text { "The different suggestions given by different } \\
\text { officers is an issue for us." }\end{array}$ \\
\hline
\end{tabular}

\section{SUGGESTIONS AND CONCLUSION}

The main objective of this study was to present outcomes that might be beneficial to SMEs in Malaysia. The findings of the research conclude that tax knowledge, SME motivation, and technology are crucial factors that affect compliance with indirect tax among SMEs. All these three variables were perceived to have positively impacted indirect tax compliance among SMEs. It was also important for SME owners to have a good motivation towards indirect tax compliance and enhance their knowledge from time to time. 
This study also contributes significantly to the theory. It has provided some empirical findings on factors related to indirect tax compliance in Malaysia from the perspective of the Responsive Regulation Theory. Some quantitative and qualitative results support the notion that compliance is affected by a few factors, as suggested by previous findings. SMEs do not support enforcement actions such as the audit and the penalty enforcement policy. However, the penalty enforcement policy and the audit must also be in place to balance out the total reliance on the above factors. These factors of enforcement are mainly carried out by the RMC and noted from the qualitative findings that the RMC had to improve its collection through audit activities among the SMEs. The finding of the research is also consistent with the Responsive Regulation Theory, which argues that technology and knowledge are fundamental parts of indirect tax compliance. Technology can be used to increase information-sharing capability with the regulator (Rorie, 2015). From a practical point of view, this study noted that tax knowledge, technology, and motivation would be applicable to SMEs to comply with the indirect tax founded by the current research and suggested by the Theory.

The pragmatic approach using an explanatory sequential mixedmethod design has indeed explained the details behind the phenomenon under research. Such an approach is gaining popularity due to its usefulness in providing meaningful and real-world understandings of results (Granek $\&$ Nakash 2016). There are, nevertheless, many areas of the study that can be further investigated. For example, various demographic segments will provide different understandings. SME, as the sample of the study, might have come short in generalizing the findings to other types of taxpayers. Other factors, such as type of education and age, could provide more information about indirect tax compliance from the perspective of a developing country like Malaysia. Secondly, the findings in the qualitative stage suggested that s will comply with tax when enforcement and audits are in place even though the quantitative results did not support the hypotheses developed.

Notwithstanding the significant contribution of this research, several limitations need to be considered. There are several limitations that have to be highlighted that covers data that has been compiled, analysed, presented and discussed in the study. First, the study relied on the individual respondent/informant to represent his/her company. This self-report survey 
might be less reliable, especially in sensitive areas such as taxation, which sometimes makes the taxpayers uneasy about answering questions, which are personal in nature (Richardson, 2008). However, the effort has been made to select the best person to represent the SMEs. A few categories of top management such as the owner of the SME, Directors, Chief Executive Officers, Chief Financial Officers, related account executives were selected to represent the SMEs. All measures of tax compliance, behaviour, and knowledge were answered by the business owners or top-level officers. Therefore, the respondents may have exaggerated their tax evaluation of their company. The actual behaviour of the subjects may vary from the responses given in the questionnaire.

Future research may explore the tax reformation for indirect tax in Malaysia. Currently, the government had shifted their primary income from indirect tax from the goods and services tax to sales and services tax. This has once again changed the indirect tax environment in Malaysia.

\section{ACKNOWLEDGEMENT}

The first author would like to thank Universiti Sains Malaysia for granting a Short-Term Grant No. 304/PMGT/6315391.

\section{REFERENCES}

Abdul-Jabbar, H., Abuamria, F. M., Alkhatib, A. A., \& Marimuthu, M. (2020). Tax evasion and the Social Influence Perspective: A conceptual model for Palestine. International Journal of Psychosocial Rehabilitation, 24(02), 4855 - 4866.

Bagozzi, R.P., \& Yi. Y. (1988). On the evaluation of structural equation model. J Acad Mark Sci, 16:74-94.

Baldwin, R., \& Black, J. (2008). Really responsive regulation. Modern Law Review, 71(1), 59-94.

Beer, S., Kasper, M., Kirchler, E., \& Erard, B. (2015). Annual report to congress: Audit impact study (Vol. 2). Taxpayer Advocate Service, USA. 
Bidin, Z., Marimuthu, M., Derashid, C., Idris, K., \& Ahmad, N. (2016). Determinants of attitude toward proposed Good and Services Tax among business communities in Malaysia. International Review of Management and Marketing, 6, 193-197.

Braithwaite, J. (2011). The essence of responsive regulation. UBC Law Review, 44(3), 476-520.

Braithwaite, V. (2007). Responsive regulation and taxation: Introduction. Law \& Policy, 29(1), 1-8.

Braithwaite, V., Murphy, K., \& Reinhart, M. (2007). Motivational postures and responsive regulation. Law \& Policy, 29(1), 1-22.

Chin, W. (1998). The partial least squares approach to structural equation modeling. In: Marcoulides G (ed) Modern methods for business research associates. Lawrence Erlbaum, Mahwah, pp 295-358.

Cohen, J. (1992). A power primer. Psychological Bulletin, 112(1), 155.

Cooper, M., \& Nguyen, Q. T. (2019). Understanding the interaction of motivation and opportunity for tax planning inside US multinationals: A qualitative study. Journal of World Business, 54(6), 101023.

Daud, H. M., Ramli, R., Jaffar, R., \& Rahmat, M. M. (2018). Siasatan cukai di Malaysia: Kajian penerokaan ke atas kes syarikat. Asian Journal of Accounting and Governance, 10, 37-48.

Devos, K. (2014). Factors influencing individual taxpayer compliance behaviour (pp. 13-23).

Diamantopoulos, A. (2009). Incorporating formative measures into covariance-based structural equation models. MIS Quarterly, 33(4), 689-707.

Fallan, L. (1999). Gender, exposure to tax knowledge, and attitudes towards taxation ; An experimental approach. Journal of Business Ethics, 18(2), 173-184. 
Farzanegan, M. R., Hassan, M., \& Badreldin, A. M. (2020). Economic liberalization in Egypt: A way to reduce the shadow economy? Journal of Policy Modeling, 42(2), 307-327.

Fornell, C., \& Cha, J, (1994). Partial Least Squares. In: Bagozzi RP (ed) Advanced methods of marketing research. Blackwell, Cambridge, pp $52-78$.

Freedman, J. (2011). Responsive regulation, risk, and rules: Applying the theory to tax practice. UBC Law Review, 44(3), 627-662.

Gale, W. G.\& Krupkin, A. (2019). Up front: How big is the problem of tax evasion? Retrieved June 18, 2019.

Gangl, K., Torgler, B., Kirchler, E., \& Hofmann, E. (2014). Effects of supervision on tax compliance: Evidence from a field experiment in Austria. Economics Letters, 123(3), 37-382.

Gefen, D., Straub, D., \& Boudreau, M. C. (2000). Structural equation modeling and regression: Guidelines for research practice. Communications of the association for information systems, 4(1), 7.

Gómez, J., \& Mironov, M. (2015). Tax enforcement, corporate governance, and income diversion: Evidence after Putin's election in 2000. Social Science Research Network, (September), 1-58.

Granek, L., \& Nakash, O. (2016). The impact of qualitative research on the "real world" knowledge translation as education, policy, clinical training, and clinical practice. Journal of Humanistic Psychology, 56(4), 414-435.

Gruber, N. (2014). The shadow economy in Israel. State of the Nation Report: Society, Economy and Policy in Israel, 11(1), 263-302.

Hair, J. F. J., Hult, T., Ringle, C., \& Sarstedt, M. (2014). Partial least squares structural equation modeling (PLS-SEM). Sage Publication. 
Hassan, N., Nawawi, A., \& Puteh Salin, A. S. A. (2016). Improving tax compliance via tax education - Malaysian Experience. Malaysian Accounting Review, 15(2), 243-262.

Heryanto, D., Mursalim, M., \& Lannai, D. (2020). Influences of tax sanctions, taxpayers awareness and social norms on motivation to meet tax obligation. Point of View Research Accounting and Auditing, 1(3), 01-11.

Hofmann, E., Voracek, M., Bock, C., \& Kirchler, E. (2017). Tax compliance across sociodemographic categories: Meta-analyses of survey studies in 111 countries. Journal of Economic Psychology, 62, 63-71.

Inasius, F. (2019). Factors influencing SME tax compliance: Evidence from Indonesia. International Journal of Public Administration, 42(5), 367-379.

IRS. (2016). Federal tax compliance research: tax gap estimates for tax years 2008-2010. Washington DC: Inland Revenue Service: Research, Analysis \& Statistics.

Isa, K. (2012). Corporate taxpayers' compliance variables under the selfassessment system in Malaysia: A mixed method approach. Unpublished PhD Thesis, Curtin University.

Jamel, N. E. S. M., \& Popoola, O. M. J. (2021). Examining public acceptance choice causes on sales and service tax implementation in Malaysia. Problems and Perspectives in Management, 18(4), 228.

Jamel, N. E. S. M., Hamid, N. A., Zawawi, S. N. H. M., Othman, R. D., \& Sulaiman, S. (2021). The Role of Tax Authorities in Public Acceptance of Indirect Tax in Malaysia. Jurnal Intelek, 16(1), 233-243.

Kline, R. B. (2011). Principles and practice of structural equation modeling. Structural Equation Modeling (Vol. 156).

Lederman, L., (2016). To what extent does enforcement crowd out voluntary tax compliance? Unpublished manuscript, Indiana University Maurer School of Law, Bloomington, U.S. 
McKerchar, M. (1995). Understanding small business taxpayers: Their sources of information and level of knowledge of taxation. Austl. Tax F., 12, 25.

Mohd Ali, R., Isa, K., \& Yusoff, S. H. (2014). The impact of threat of punishment on tax compliance and noncompliance attitudes in Malaysia. Procedia - Social and Behavioral Sciences, 164(July 2016), 291-297.

Pope, J., \& Mohdali, R. (2010). The role of religiosity in tax morale and tax compliance. Australian Tax Forum, 25(January 2011), 565-596.

Richardson, G. (2008). The relationship between culture and tax evasion across countries: Additional evidence and extensions. Journal of International Accounting, Auditing and Taxation, 17(2), 67-78.

Rorie, M. (2015). Responsive regulation. UK: Oxford University Press.

Sakurai, Y., \& Braithwaite, V. (2019). Taxpayers'perceptions of the ideal tax adviser: Playing safe or saving dollars? Centre for Tax System Integrity (CTSI), Research School of Social Sciences, The Australian National University.

Sanusi, S., Omar, N., M.Sanusi, Z. \& Noor, R. (2018). Goods and Services Tax compliance initiatives: Examining corporate taxpayers' and regulator's responsibilities in Malaysia. Contemporary Social Sciences, 27(3), 182-193.

Slemrod, Joel. (2019). Tax Compliance and Enforcement. Journal of Economic Literature, 57 (4), 904-54.

Start reading revolution (2020, January 9,). New Straits Times. Retrieved from https:/www.nst.com.my/opinion/leaders/2020/01/554748/nstleader-start-reading-revolution

Tsang, R., Mehta, V., Lee, N., \& Wong, W. G. (2015). Malaysia GST Compliance Made Easy. (W. Kluwer, Ed.). Kuala Lumpur: Commerce Clearing House (Malaysia) Sdn Bhd. 
Venkatesh, V., Morris, M. G., Davis, G. B., \& Davis, F. D. (2003). User acceptance of information technology: toward a unified view. MIS Quarterly, 27(3), 425-478.

Yusof, N. M., Ling, L. M., \& Wah, Y. B. (2014). Tax noncompliance among SMEs in Malaysia: Tax audit evidence. Journal of Applied Accounting Research, 15(2), 215-234. 